\title{
MATTHIAS JOHANN EISEN \\ JA TEMA KAASTÖÖLISED SEITSME MOOSESE PÄRIMUST PIIRITLEMAS
}

\author{
KATRE KIKAS
}

\section{Sissejuhatus}

\section{Ü}

heksateistkümnenda sajandi lõpukümnendil toimunud rahvaluule suurkogumise käigus pandi alus kahele Eesti Rahvaluule Arhiivis hoiul olevale suurele kogule - Jakob Hurda ja Matthias Johann Eiseni kogudele. Kahe suure organiseerija tegevust on sageli vaadeldud vastandavalt, rõhutades Hurda teaduslikku ja süstemaatilist ning Eiseni ebateaduslikku ja süsteemitut lähenemist. Etteheiteid on põhjustanud ka Eiseni komme kogutav kohe trükki anda (vt nt Anderson 1938; Tedre 1994; Kuutma 2005; Kikas 2013). Samas on esile toodud ka seda, et Eisen mitte üksnes ei kopeerinud Hurda tegevust, vaid tõi kogumistöö keskmesse teemasid ja žanre, mis Hurda tähelepanu alt välja jäid (Päss 1938: 139; Tedre 1996: 175).

Eiseni kogu olulisimaks märksõnaks on (tänapäevaseid termineid kasutades) projektipõhisus - ühe tervikkogu asemel on meil erinevate väiksemate (kuid seostuvate) projektide raames laekunud materjalid. Projektid eristuvad üksteisest ühelt poolt temaatiliselt: ehkki Eisen oli tänulik igasuguse rahvaluule eest, juhtis ta kaastööliste tähelepanu konkreetsetele teemadele, süžeedele või laulutüüpidele, millega seonduvat ta mõne väljaande jaoks vajas. ${ }^{1}$ Teiseks projekte eristavaks jooneks oli erinevate suhtluskanalite kasutamine. Nagu Hurdalgi, oli peamiseks kanaliks ajakirjandus, kuid Eisen tegi koostööd tunduvalt suurema hulga väljaannetega ning nende hulk ja nimetused olid ajas väga varieeruvad. Samavõrd olulised olid ka jutukogumikele lisatud üleskutsed lisamaterjali saatmiseks, auhinnamängud kalendrites ning isiklik kirjavahetus. Oluline osa Eiseni kogumistööst oli kaastööliste tasustamine raamatutega. Raamatud olid ühelt poolt võimalus kogujat tänada, kuid raamatusaadetiste kaaskirjad andsid võimaluse pöörata koguja tähelepanu teemadele, kust oleks veel materjali vaja. ${ }^{2}$ Väljapakutud teemast ja kasutatud meediumist sõltus, kelleni info jõudis ning kes tundis tõuget kaasalöömiseks oli nii neid, kes saatsid infot vaid ühe konkreetse teema kohta, kui ka neid, kes üritasid jõudumööda kõige kohta midagi kirja panna; oli nii neid, kes vastasid

\footnotetext{
${ }^{1}$ Täiesti omaette teema on see, kust pärinevad impulsid erinevate projektide käimalükkamiseks. Eiseni esimeseks huvialaks olid mõistatused (vt Saukas 2003) ning huvi teiste teemade vastu oli tingitud osaliselt sellest, et kogujad saatsid ka muud. Mitmed teemad lähtuvad aga tema soome kolleegide huvidest.

${ }^{2}$ Ka Hurt saatis aeg-ajalt kogujatele raamatuid, kuid reeglina oli tegu tema enda koostatud rahvaluuletrükistega (nt Vana Kannel) ning need saadeti laiali kõigile kaastöölistele üheaegselt. Eiseni eripäraks oli aga see, et raamatud, mida ta kogujatele saatis, ei olnud üksnes rahvaluuleteemalised - sekka sattus ka ajalugu, romaane, religioosset kirjandust, luuletusi, karskusteemalisi väljaandeid jpm, ning see, kui palju raamatuid üks või teine koguja sai, sõltus isiku panusest.
} 
vaid konkreetse meediumi üleskutsele, kui ka neid, kes jõudsid jälgida mitmeid kanaleid. Siiski on oluline märkida, et Eiseni kogumistöö projektipõhisus ei kajastu väga üheselt arhiivitasandil - kuna ta küsis enamasti üheaegselt eri teemade kohta, ongi need käsikirjades segiläbi. Eiseni kogumistegevuse vaatlemine erinevate projektidena on hea võimalus tuua esile see, mis eristas tema tegevust Hurda omast - Hurda läbivalt numereeritud ning sarnaselt pealkirjastatud aruanded rõhutasid kogumistööd kui üht aina jätkuvat ja tulevikku suunatud ettevõtmist. Samas seadis Eisen järjepanu üha uusi (ning kiiremini saavutatavaid) eesmärke.

Käesoleva artikli kese on temaatiline - ma vaatlen Eiseni kogus leiduvaid rahvajutte kuuendast ja seitsmendast Moosese raamatust. Need nn seitsme Moosese lood kõnelevad inimeste kokkupuudetest raamatutega, mis väidetavalt on kunagi olnud piibli osaks, kuid hilisemal ajal ühel või teisel põhjusel sealt välja arvatud. Seitsme Moosese raamat võib oskajale käsitsejale anda mõjuvõimu, oskamatule uudishimulikule tuua kaasa aga üsnagi ohtlikke olukordi. Siiski ei keskendu ma mitte kõigile Eiseni kogus leiduvatele seitsme Moosesega seotud teadetele, vaid aastatele 1893-1896, mil ta koondas materjale, et koostada teos „Seitse Moosese raamatut. Katse kuuenda ja seitsmenda Moosese raamatu seletuseks" (Eisen 1896a). Lähenen neile materjalidele, pidades eelkõige silmas teadusloolist küsimust lugude teekonnast raamatusse: mida ja kuidas Eisen küsis, mil moel kogujad tema üleskutset mõistsid ning allikate sõnu kirja panid ning mida Eisen temani jõudnud materjalidega peale hakkas.

Seitsmele Moosesele keskenduva projekti muudab eriliseks see, et Eiseni üleskutsete eelsest ajast on Eesti Rahvaluule Arhiivi kogudes väga vähe seitsme Moosesega seotud materjali. ${ }^{3}$ Võimalik, et seda materjali peeti kas liiga kristlikuks või kirjasõnaga seotuks, et seda eesti rahvaluule hulka hõlmata. Seega võib öelda, et küsides seitsme Moosese järele, avardas Eisen kogujate jaoks rahvaluule kontseptsiooni - viimane tähendas aga ühtlasi ka seda, et Eiseni ja kogujate koostöös toimus selle rahvaluulevaldkonna piiritlemine. Charles L. Briggsile (1993: 391) toetudes võib öelda, et Eisen ja tema kaastöölised tegelevad seitsme Moosesega seotud intertekstuaalse välja loomisega, ning järgnevalt vaatlen, milliseid võimalikke seoseid nad seda välja luues esiplaanile toovad ning millised tähtsusetuna kõrvale jätavad.

\section{Seitsme Moosese pärimus: üldisemaid lähtekohti}

Seitsme Moosese pärimuse lähtekohaks on uskumus, et kunagi ammu oli piiblis kaks Moosese raamatut rohkem ning neis kahes raamatus olid kõige võimsamad nõidused. Uskumus on rahvusvaheliselt väga laia levikuga ning traditsioon on tagasiviidav vähemalt esimese sajandini $\mathrm{pKr}$ (geograafilisest levikust annavad hea ülevaate Eisen 1896a ning Anderson 1929a, 1929b; ajalise dimensiooni kohta vt Anderson 1929a: 29).

\footnotetext{
${ }^{3}$ ERA kartoteegi andmetel on varasemalt vaid üks lugu Eiseni enda kogus ning kümmekond Jakob Hurda kogus. Samas tuleb arvesse võtta, et kartoteegid ei sisalda alati kõike, mis arhiivis reaalselt olemas on. Siiski võib eeldada, et järsk laekumiste kasv Eiseni projekti ajal on nähtav ka siis, kui varasemate üleskirjutuste hulk osutub kaks või kolm korda suuremaks.
} 
Eesti traditsioonis kõige levinum seitsme Moosesega seotud süžee kõneleb inimesest, kes juhtumisi raamatut loeb ja satub olukorda, kust ta omal jõul enam välja ei pääse (AaS 107). Viimasele lisanduvad teated selle kohta, kuidas raamatud välja näevad, kellel neid veel on, miks neid nii vähe liikvel on ning kunas ja miks nad avalikust käibest kadusid. Raamatute omanikena kujutatakse sageli kirikuõpetajaid ja mõisnikke (nemad on enamasti seotud ka raamatute ärakorjamisega), rikkaid talumehi (selgitus rikkusele) või nõidu (selgitus nende nõiavõimete päritolule). Žanriliselt on seitsme Moosese pärimuse keskmeks muistendid ja memoraadid, kuid tugevalt on esindatud ka kuulujutu element - suur osa pärimusest koosneb vihjetest stiilis „tollel seal on mingi imelik vana raamat, vist on seitse Moosest".

Seitsme Moosese pärimust on keerukas piiritleda - on küll mõned süžeed, mis ei toimiks ilma viiteta seitsmele Moosesele (eelkõige AaS 107), kuid seitsme Moosese raamat võib ilmuda nõia abivahendina ka süžeedes, kus enamasti saab ka ilma hakkama (nt selle kasutamine kodukäija kinnipanemiseks, vt E $6239 / 40$ < Ambla khk - Karp Kuusik) või on seitse Moosest kätketud jututüüpi, kus enamasti kasutatakse hoopis tavalist piiblit. Seitsme Moosese lugudel on ka seoseid rumala vanapagana lugude (jututüüp ATU 1174 kui võimalus AaS 107 õnnelikuks lahenduseks, vt nt E 6323/4 < Narva - Johan Landsmann), hiiumuistendite (AaS 107 kui selgitus mingile pinnavormile, vt nt E 3987/8 < Ambla khk - K. Kuusik) ja aardemuistenditega (nt E 13796/7 < Pilistvere khk - Hans Keller; E 16294 < Narva - August Valts). Lisaks nimetusele seitse Moosest või kuues ja seitsmes Moosese raamat kohtame lugudes ka nimetusi suur piibel / raamat, must raamat või nõia raamat/piibel, (vana) piibel või lihtsalt viiteid vanale ja eriskummalise välimusega raamatule, millele otseselt nime ei antagi. Seitse Moosest võib lugudes ilmuda nii konkreetse esemena, mille kohalolu loob erilise situatsiooni, kui ka allikana, kust pärit sõnadega midagi korda saadetakse.

Seitsme Moosese pärimuse mõtestamisel on oluline vaadelda teda vähemalt kahe avarama valdkonna taustal. Ühelt poolt laveerib see rahvausu ja konfessionaalse kristluse, teisalt aga suulise ja kirjaliku tekstiloome vahelistel võrdlemisi hägustel piiridel - arvestades seda, et veel XIX sajandi keskpaiku oli eestikeelne kirjasõna peamiselt religioosne, pole võimalik neid kaht ka väga selgelt eristada. Traditsiooni lähtekoht (kunagi oli piiblis rohkem raamatuid) asetab seitse Moosest ühtaegu kanoonilise kristluse raamidesse ning samas ka eemaldab selle sealt. On üsnagi põnev, et raamatute omanikeks on sageli just kirikuõpetajad, ehkki raamatu sisuna kirjeldatakse enamasti seda, mida me tänapäeval peame pigem suulise rahvakultuuri kui konfessionaalse kristluse osaks (nt väidetakse loitsud pärinevat seitsmest Moosesest). Viited päritolule on omamoodi võte lülitada rahvausu praktikad kristluse korpusesse, teisalt ka katse ametliku ja mitteametliku, suulise ja kirjaliku hierarhilist suhet lammutada või ümber pöörata.

Tegelikult on seitsme Moosese lood vaid üks osa siin viidatud valdkondade piiridel tekkinud nähtusest, mida võiks üldisemalt nimetada raamatupärimuseks - rahvaluuleks, kus kirjutamisel ja/või kirjutatud tekstidel on mingi roll täita. Siia alla käiks näiteks raamatute kasutamine maagilistes toimingutes, loitsu lugemise asemel selle kirjutamine või kirjutamise imiteerimine, tähendused, mis omistatakse unenäos nähtud raamatule, naljandid lugema õppimisest ning õpetused, kuidas seda oskust paremini omandada jpm (näiteid 
enamikust siin toodust leiab käsitlustest Paatsi, V., Paatsi, K. 2008; Kõiva 2014). Kõik need on suulisse kultuuri kuuluvate (või esimese põlvkonna kirjaoskajate) kommentaarid kirjalikule kultuurile.

Suulise ja kirjaliku pärimuse vahekorra puhul tuleb arvestada ka reaalsete kirjutiste mõju. Näiteks on 1872. aastal ilmunud „Kues ja seitsmes Mosese Raamat”. Tõsi - tegu pole maagiliste õpetuste kogumiga, vaid ühe mittekanoonilise piiblilooga, ent asjaolu, et väljaanne õige pea pärast ilmumist ära keelati, andis alust mitmetele oletustele selle sisu kohta (vt nt E 6230/1 < Vastseliina khk - August-Andreas Kuuben). Sisu poolest on see raamat lähedane nn rahvalikule käsikirjakultuurile - peamiselt vennastekoguduse vahendusel liikus rahva seas ümberkirjutusi erinevate mittekanooniliste kristlike tekstide tõlgetega (vt Põldmäe 2011). Kuivõrd kirikuõpetajad suhtusid neisse tekstidesse taunivalt, käsitleti neid rahva seas mõnikord kui „piiblist mingil põhjusel välja arvatud osasid" - ehk siis üsnagi samas raamistuses seitsme Moosesega (selle lähenemise heaks näiteks on rahvaluulekoguja Hans Anton Schults). Mõned rahvaluulekogujad on ka seitsme Moosese sisuna kirjeldanud ilmselt käsikirjakultuuri kaudu tuttavaid süžeid (nt Märt Siipseni kirjeldus näib viitavat nn „Nikodeemose evangeeliumile”, vt E 20631/6 < Rõuge); ka on ERA kogus mitmeid käsikirju, mil pealkirjaks „Kuues ja seitsmes Moosese raamat”, kuid sisuks hoopiski nn taevakirjad (vt Anderson 1929a: 32).

Seitsme Moosese lood on saanud inspiratsiooni ka eestikeelse piibli erinevate trükiversioonide võrdlemisest. Eisen oletab, et sagedased viited seitsme Moosesega piibli punasele kirjale võisid tuleneda sellest, et eestikeelse piibli kõige esimesel trükil oli punases kirjas tiitelleht (Eisen 1896a: 114). Lugude levikut võis mõjutada seegi, et piibli varastes trükkides oli ka apokriiva, hilisemates aga enam mitte - seda võimalust kaaluvad näiteks kogujad Märt Siipsen (E 20631/6 < Rõuge) ja Jaak Hünerson (E 12060/6 < Karksi). Koguja Johan Abreldal kirjutab aga, et kui keeleteadlane Eduard Ahrens käis Kuusalu kandi rahva käest vanu piibleid küsimas, tekkisid kuulujutud, et tema eesmärgiks on seitsme Moosesega versioonide leidmine ja äravõtmine (vt E 9734, Eisen 1896a: 57).

\section{Mida ja kuidas Eisen küsis?}

Esmakordselt mainib Eisen oma huvi seitsme Moosese vastu 1893. aasta märtsikuise aruande lõpus. ${ }^{4}$ Seitse Moosest leiab seal mainimist teiste teemade hulgas:

Nagu nimetatud, on kõik rahvaluule mulle armas. Iseäranis sooviksin aga järgmiste küsimiste kohta rohkesti teadust: Mis arvab ja räägib rahvas „kollist”? Kuidas pidas vana rahvas jõulu ja jaanipäeva? [---] Mis räägib vana rahvas 7. Moosese ja musta raamatu kohta? Ehk annab mõni peale muu ka nende küsimiste kohta seletust. Mida rohkem seletust seda parem (Eisen 1893a, Sakala; minu rõhutus $-K$. K.).

${ }^{4}$ Eiseni erinevates ajalehtedes ilmunud aruannete sõnastused polnud päris kattuvad. Viidates olen ma sellest hoolimata hõlmanud samasisulised aruanded ühe nimetuse alla, kuna leian, et see annab parema võimaluse jälgida, kui mitmes versioonis üks või teine neist levis ning kui pikad võisid olla vahed samade tekstide ilmumise vahel. Seostades üht või teist aruannet konkreetse kuuga, lähtun kõige varasemast ilmumisajast - Eisen ise oma aruandeid ei dateerinud. 
Kuni 1893. aasta lõpuni avaldab Eisen ajakirjanduses igakuiseid aruandeid ning pea kõigis neis saab ta raporteerida ka seitsme Moosesega seotud materjalide laekumisest (Eisen 1893b, 1893c, 1893d, 1893e, 1893f, 1893g, 1893h, 1893i, 1893j, 1893k, 1893l, 1893n, 1893o). Et aga laekumised pole väga ohtrad, lisab ta lihtsale äramärkimisele ka teistele kogujatele suunatud õhutusi. Näiteks:

Kroonlinnast tõi mulle E. Kitzberg mõnusa kirjelduse 7 Moosese kohta. Peale Kitzbergi on tänini niisuguse kirjelduse veel O. S. Hallistest saatnud, kui ka teadusi kolli kohta. Sooviksin väga, et niisugusid kirjeldusi õige rohkeste saaksin. Teab ju ometi rahvas igal pool 7 Moosese ja kolli kohta enam ehk vähem rääkida. Ehk leiavad mõned virgemad sulemehed mahti neid täiendada (Eisen 1893b, Sakala).

Kui esimestes üleskutsetes piirdub Eisen vaid teema vastu huvi ülesnäitamisega, siis 1893 aasta sügisel (Eisen 1893f, 1893m) läheb ta mõnevõrra konkreetsemaks ning märgib, et plaanib koostada sel teemal eraldiseisva raamatu:

Seitsme Moosuse jaoks tarvitaksin nimelt veel rohkesti materjali. Hea oleks kui kõiki rahvaarvamisi 7 Moosuse kohta teada saaksin, et raamat võimalikult täielik võiks saada. Hulk materjali on mulle seks küll juba saadetud ja see on ka ju trüki vasta valmistatud, aga tarvis läheks veel küll (Eisen 1893f, Eesti Postimees).

1894. aasta alguses aruannete ilmumine katkeb ning novembrini ei ilmu Eisenilt ajakirjanduses ühtegi rahvaluuleteemalist sõnavõttu. Samas materjalide (sh ka seitsme Moosesega seotu) laekumine siiski jätkub. Esimeseks pausijärgseks sõnavõtuks saab spetsiaalselt seitsmele Moosesele keskenduv kirjutis „7. Moosese raamatu kohta”. Eisen tänab nimeliselt kõiki, kes on talle vahepealse aja jooksul seitsme Moosesega seotud materjale saatnud, annab ülevaate töö seisust ning ergutab lugejaid veel materjali saatma, rõhutades, et „Raamat peaks aga võimalikult täielik saama” (Eisen 1894a, Postimees).

Kuu hiljem ilmub teinegi samalaadne kirjutis „Veel 7 Moosesest”. Taas tänab ta kõiki, kes on midagi juba saatnud, seejärel aga annab esmakordselt täpsemaid juhiseid selle kohta, mis laadi info teda huvitab:

Mõned aga ei ole mu soovi 7 Moosese kohta üsna õieti mõistnud: nad arvavad, et ma ainult sellekohaseid vanu juttusid soovin. Teiselt poolt jälle on küsitud, missuguseid teateid 7 Moosese kohta ma nimelt nõuan. Selle kohta siin sõna seletuseks. Iga teade, olgu ka see kõige vähem, rahva arvamisest 7 Moosese kohta on mulle tähtjas ja tuleb seega kirja panna. Näituseks: missugune 7 Moosese raamat olnud, mis temaga tehtud; kell ja kus r. olemas; kuhu raamatud jäänud ja palju muud sellesarnast; siis vanad jutud 7 Moosese kohta; s. o. see, mis meie ajal mõne 7 Moosese mehe tegudest kuulda. - Lühikesi teateid 7 Moosese kohta saadetagu postkaardiga (Eisen 1894b, Eesti Postimees).

1895. aasta suvel annab Eisen märku, et on seitsme Moosese teemal otsi kokku tõmbamas. Nii märgib ta koerakoonlastele keskenduva üleskutse lõpus: „Hää meelega näeksin ka, et veel teateid 7 Moosese kohta tuleks. Siis võiks 
seda tööd lõpetada" (Eisen 1895a). Suve jooksul tänab ta veel mitmes aruandes seitsme Moosesega seotud laekumiste eest (Eisen 1895b, 1895c, 1895d), sügisel ilmub aga ajakirjanduses teade käsikirja valmimisest (Kirjandusest 1895).

Eiseni üleskutsetele vastas ligikaudu 60 inimest, ${ }^{5}$ neist 12 saatsid materjali rohkem kui ühel korral. Enim saatnud kogujate hulka kuulusid kooliõpetaja Otto Hintzenberg Koerust, metsavaht Jaak (J. P) Sõggel Hallistest, kooliõpetaja Jaan Karu Helmest, tisler K. Kuusik Amblast, rätsep Joosep Neublau Amblast ja põllumees Danel Pruhl Haljalast - kõik mainitud olid ka muidu väga aktiivsed Eiseni kaastöölised. Enamik kaastöölistest olid Eestist, kuid üht-teist saadeti ka Soomest ja Lätist (Eisen on pöördunud enamasti isiklikult oma sealsete kolleegide poole).

Oma järgnevas käsitluses viitan lugude allikana eelkõige kogujatele, põhjuseks on see, et väga vähesed neist mainivad oma allikate nimesid, pigem kohtame käsikirjades märkusi, nagu „siinse rahva suust” või „kuulsin lapsepõlves". Ka teised uurijad on märkinud, et XIX sajandi materjalides on koguja pea alati (kaas)jutustaja ning arhiivitekstid mitmehäälsed tervikud, kus kõlavad kaasa erinevad varasemad jutustamissituatsioonid ning neis osalenud inimeste kogemused (Järv 2005: 39, 46; Valk 2008: 62; Soome rahvaluule kogude kohta on sama väitnud Kurki 2002: 106).

\section{Mida (ja kuidas) kogujad kirjutasid?}

\subsection{Lugude piiritlemine}

Ehkki Eisen juhib projekti lõpufaasis tähelepanu sellele, et ootab lisaks lugudele ka muid teateid, on enamik laekunust siiski narratiivne. Põhjuseks võis olla see, et narratiivide puhul kujutasid kogujad natuke selgemalt ette, mida Eisen nendega teha kavatseb - ilmselt olid nad kõik mõne Eiseni koostatud raamatuga varasemalt kokku puutunud. Samal ajal on huvitav, et väga vähesed kogujatest üritasid vormistada lugusid nii, nagu neid rahvajutukogumikes tol ajal üldiselt esitati - iga narratiiv kui eraldiseisev pealkirjastatud üksus. Erandiks olid J. P. Sõggla ja Peeter Rootslase saadetised (vt E 13862/84 < Halliste khk; E 16284/97 < Võnnu khk) - eriti just J. P. Sõggla puhul võib näha selget soovi luua tervik, mis vormistuselt oleks võimalikult lähedane trükitud jutukogumikele.

Tavapärasem oli erinevate lugude ja muude teadete kokkupõimimine. See põimik võis olla vormistatud kui kiri (vastus Eiseni konkreetsele järelepärimisele, mis üritas anda võimalikult korraliku ülevaate kohapeal teada olevast), postkaart (samuti vastus Eiseni järelepärimisele, kuid kirja pandud fragmentaarsemalt) või suuremasse saadetisse hõlmatud pala, millele kogujad andsid üldisemalt seitsmele Moosesele viitava pealkirja (nt „Teateid 7 Moosese kohta”, E 3479/80 < Viljandi khk - J. Pihlap) - pealkirja funktsiooniks oli ilmselt juhtida Eiseni tähelepanu tema poolt küsitud materjalile.

\footnotetext{
${ }^{5}$ Päris täpset arvu on raske öelda - Eisen tänab raamatus 49 inimest, kuid kaastöölisi oli kindlasti rohkem. Näiteks jäävad seal mainimata D. Kõrv, J. Laan, A. Landsmann, samuti on puudu kõik välismaalased, kelle panusele viitab Eisen konkreetse maa kohta käivate peatükkide juures. Lisaks on Eisen ka ise seitsme Moosese lugusid kogunud.
} 
Kirju või postkaarte saadavad enamasti kaastöölised, kellel pole aega kogumisega ulatuslikumalt tegelda, kuid on ka mõningaid erilisemaid juhtumeid. Näiteks tunnistab J. Hünerson Eisenile, et ehkki ta on Jakob Hurda kaastööline, otsustas ta saata seitsme Moosesega seotu justnimelt Eisenile, seda ei tee ta aga mitte üksnes soovist panustada raamatu valmimisse, vaid lootuses, et Eisen oskab teema kohta midagi konkreetsemat avaldada:

\section{Minu mõte ja soov.}

Mõnelgi Eesti rahva vanal jutul on natuke põhja all ja sellepärast on minu arvamine et ka 7. Moosuse raamatu jutt just ilma põhjata ei ole. Mina ei ole sugugi eba usklik ega tahagi olla mulle aga näitab et on ühes kõige vanemas Eesti keelses Piibli trükis misgisugust lisa olnud, nimetatagu teda 7 Moosuse nimega ehk kuda tahes: teil on auus suguvend see asi täitsa teada, seepärast palun südamest sellest asjast kirja teel mulle natuke avaldada. On salgamist kristlikule rahule tarvis, - siis sündku see nõnda mul ei ole selle vasta midagi ega seda kirjakest pääle minu keegi teada ei saa. Ühtlasi sooviksin teada millas saab Teie korjatud 7. Moosust trük. ilmuma.

(E 12060/6 < Karksi khk)

Kirjad ja palad võivad olla ka mingil määral sisemiselt struktureeritud. Näiteks J. Neublau pala „6. ja 7. Moosese raamatu tükkid” erinevad alaosad algavad: „Teine sellesarnane lugu sündinud... Kolmas selle sarnane lugu sündinud Esna mõisas... Neljantaks. Ambla surnu ajal..." (E 10609/12 < Ambla khk). On aga ka tervikuid, kus üldisemad kirjeldused, kontekstuaalsed vihjed ja narratiivid üksteiseks sujuvalt üle lähevad, heaks näiteks sellest on J. Abreldali tekst „Seitsmest Moosese raamatust” (E 9734/48 < Kuusalu khk) - koguja on kokku põiminud erinevatelt allikatelt kuuldu, isiklikud lapsepõlvemälestused, narratiivid jm teated.

\subsection{Traditsiooni piiritlemine}

Saadetiste kaaskirjadest jääb mulje, et seitsme Moosese teema on raskesti kogutav valdkond. Mitmed neist kurdavad, et ei suuda oma kodukohast midagi leida (nt E 6126 < Tõstamaa khk - Jakob (J. A.) Weltmann; E $9950<$ Tarvastu khk - J. Kuusk) või et inimesed ei luba teatud asju kirja panna (nt E 14736/7 $<$ Halliste khk - J. P. Sõggel). Ka tuleb ette, et sama isiku kohta kõneleb üks allikas üht ja teine teist. Näiteks kirjutab Helene Maasen, et rahvas omistab ühele juba surnud ravitsejale seitsme Moosesega ravimist, ent kui H. Maasen mõni aasta varem selle ravitsejaga kohtunud oli, väitis too, et ravib jumalasõnaga (E 10264/5 < Palamuse khk). Segadust suurendab seegi, et ilmselt muidu sobiva sisuga lugudes pole raamatut alati väga selgelt määratletud - näiteks J. Abreldal kirjutab, et ühel ravitsejal oli „üks vana raamat”, aga „kas se siis se Seitse Moosest oli ei tea ka need inimesed, kes seda vanamehe käes nägivad" (E 9735/6 < Kuusalu khk). Jakob Tamm aga on oma kirjutisse paigutanud loo, kus ravitseja ravib otsesõnu „puhta jumala sõnaga”: tekstis on küll viidatud, et need sõnad pärinevad „suurest piiblist”, samas võib suur piibel viidata nii seitsme Moosesega piiblile kui ka lihtsalt tavalisele piiblile, kus on kõik osad olemas (E 6268/9 < Oudova < Põlva khk). ${ }^{6}$

\footnotetext{
${ }^{6}$ Näiteks koguja M. Siipsen nimetab suureks piibliks seda väljaannet, kus on olemas ka
} 
Üldiselt tulebki nentida, et pealkirja „Seitse Moosest” alla on kogujate kirjapanekutesse sattunud üsnagi eriilmelist materjali ning kohati ka sellist, mille seost teemaga on kõrvalt vaadates raske hoomata. Võimalik, et kogujate ja/või jutustajate jaoks oli seitsme Moosese teema nii tugevalt seotud teiste rahvausu valdkondadega, et seda oli raske eraldi käsitleda. Üheks tavaliseks kõrvalekaldumise kohaks on märkus, et loitsud pärinevad seitsmest Moosesest - nii mitmelgi juhul järgneb näiteid muudest loitsudest või nende kasutamisest (nt E 9734/6 < Kuusalu khk - J. Abreldal, E 8027b < Ambla khk - K. Kuusik). Teiseks kõrvalekaldumist soodustavaks detailiks on viide mõnele reaalsele seitsme Moosese omanikule - võivad järgneda sama isikuga seotud lood, mis aga seitsme Moosese teemat otseselt ei täienda. Näiteks J. Neublau pala „6. ja 7. Moosese raamatu tükkid” koosneb kahest narratiivist, millest esimeses pole üldse mingit viidet raamatule, teises aga loeb kirikuõpetaja määratlemata raamatut (E 10621/2 < Ambla khk). Samas on esimese loo peategelaseks Ambla õpetaja A. Paulsen, ${ }^{7}$ kes on vägagi sageli lugudes seitsme Moosese omanikuks.

Nii võib öelda, et rahvaluulekogujate kirjapanekud peegeldavad kindlasti suulise kultuuri hämarust ja ambivalentsust, seda, et seitsme Moosesega seonduvat polegi nii lihtne muu rahvaluule kontekstist eraldada. Teisalt võib aga näha kogujate soovi aktiivselt Eiseniga kaasa mõelda ning neile kättesaadavaid pudemeid mingilgi moel ühtsesse raami paigutada.

\section{Mida Eisen lugudega tegi?}

Ülo Tedre on jaganud Eiseni rahvajutuväljaanded kolmeks: 1) kogumikud, mis sisaldavad oluliselt muutmata kujul Eisenile saadetud tekste; 2) kogumikud, kus tekste on ühendatud nn ideaalseteks variantideks; 3) väljaanded, kus tekstidele eelneb pikem sissejuhatus (Tedre 1995: 168). Ehkki Tedre seda ei täpsusta, sarnanevad kolmanda rühma väljaannetesse koondatud rahvajutud pigem esimese kui teise rühmaga: tekstid on esitatud enam-vähem sellisena, nagu kogujad nad kirja on pannud, ning Eisen pole üritanud teisendeid ühendada.

„Seitse Moosese raamatut. Katse kuuenda ja seitsmenda Moosese raamatu seletuseks" kuulub Tedre klassifikatsioonis kolmandasse rühma. Raamat koosneb kahest jaost: teoreetilis-ajaloolisest sissejuhatusest (mis muuhulgas annab ülevaate ka pärimuse geograafilisest levikust) ning lugude kogumikust; järgneb lisa, kuhu on paigutatud kolm memoraadilaadset jutustust. Kõigis kolmes osas on Eisen toetunud ka kaastöölistelt saadud materjalidele: esimeses jaos on kaastöölistelt saadu põimitud Eiseni enda teksti sisse (kogujate nimed on antud alamärkustes), teises jaos ja lisas on nende panus selgemalt esil. Jutukogumikus on 60 lugu 26 kogujalt (sh kolm Eiseni enda kogutud lugu) - kõige enamate lugudega on esindatud J. P. Sõggel (10 lugu), O. Hintzenberg (8 lugu) ja P. Rootslane (6 lugu).

apokriiva raamatud; sellele vastandub odavam rahvaväljaanne, kus neid pole (vt E 20631/6 $<$ Rõuge khk).

${ }^{7}$ Tõenäoliselt on lugudes silmas peetud Alexander Leopold Paulsenit (1804-1877), kes oli aastatel 1834-1877 Ambla Maarja koguduse õpetaja. 


\subsection{Lugude piiritlemine}

Kogujate kirjapanekute ja Eiseni raamatus olevate tekstide võrdlemisel paistavad esimesena silma lausestuse ja õigekirjaga seotud muudatused: Eiseni laused on lühemad, kirjavahemärgistus ja õigekiri standardiseeritud. Mõningate kogujate puhul on need muudatused pigem marginaalsed, mõnede puhul on lausete lühendamise tulemusel läinud kaotsi algse kirjapaneku „suuline” jutustamisstiil. Samas on oluline tähele panna, et sedalaadi muudatusi kogujad Eisenilt eeldasidki - enamik neist vabandab oma vähese kirjutamiskogemuse pärast ning palub enne trükis avaldamist kirjutatu kindlasti ära parandada.

Lausestuse ja õigekirja ühtlustamisele lisandub aga ka küsimus narratiivide piiritlemisest, viimast eriti juhul, kui algkäsikirjas olid narratiivid põimitud pikema pala koosseisu. Käsikirjas eelneb narratiividele sageli jutustuskontekstile või koguja/jutustaja arvamusele viitavaid raame. Näiteks A. Bormanni kirjapandud lugu algab jutustaja Hans Völmani kinnitusega, et ta usub seitsme Moosese olemasolusse. Eiseni versioonis on alles jäänud vaid nn puhas narratiiv:

Nii palju kui mina seitsmest Moosese raamatust tean, ehk noored inimesed küll ei taha uskuda, et seitsed Moosese raamatud on. Aga mina usun küll et on. Ehk mispärast teda ei peaks olema, kust õppisid vanad inimesed niisugusid kunste ja nõidust? kõik sellest seitsmest Moosese raamatusd. Et neid enam ei ole sellepärast ei mõista nüidse päeva inimesed midagi niisugusest vägevatest asjadest.

Minu vana isa jutustas kui mina ales veikene poisikene olin, „Kord elanud ühes rikkas talus üks peremees...”
Korra elanud ühes peres rikas peremees. Tema koht olnud külast kaugel ja sellepärast puutunud ta harva külarahvaga kokku. Kõik külarahvas, noored ja vanad, kartnud teda. Teda nimetatud nõiaks ja lausujaks.

Kaugemalt käinud inimesed tihti ta juures abi otsimas. Kell olnud käe- ehk jala luu murdunud, kell luu asemelt ära nikastanud, kell haigus kallal. Ikka tuldud sinna peresse abi saama ja saadud ka abi (Eisen 1896a: 138).

\section{A. Bormann < Hans Völman, E 6277/9}

Algus- (ja lõpu-) raamide väljajätmine vähendab ühelt poolt arhiivitekstidele omast mitmehäälsust, teisalt aga minimeerib ka lugude seoseid reaalse maailmaga ning nihutab neid memoraadi ja muistendi žanrist muinasjutu žanri poole.

Selliseid jutustuskontekstiga siduvaid raame asendab Eiseni raamatus pealkiri - sealjuures on enamik pealkirjadest Eiseni enda pandud. Pikematest paladest väljavõetud narratiivide puhul on see paratamatu - olid ju neile pandud pealkirjad väga üldised ja mõeldud pigem Eiseni tähelepanu köitmiseks kui narratiivi sissejuhatamiseks. Tähelepanuväärne on aga see, et Eisen on otsustanud omaloodu kasuks sageli ka siis, kui lugu on juba käsikirjas pealkirjastatud: 57 kogumikku hõlmatud tekstist ${ }^{8}$ on algkäsikirjas pealkirjastatud 16 , neist vaid viis on sama pealkirjaga ka kogumikus.

${ }^{8}$ Tekstid number 44, 57 ja 60 on Eiseni enda kogutud ning seetõttu jätan nad sellest arvutusest välja. 
Uurijad pole läbini üksmeelel selles, kuivõrd on võimalik rääkida lugude pealkirjastamisest suulises kultuuris: Risto Järv on pakkunud välja, et see sõltub eelkõige sellest, kui iseseisvana mingit narratiivi tajuti, ning viidanud, et imemuinasjuttudel midagi pealkirjalaadset kindlasti eksisteeris. Samas ei välista ta võimalust, et tegu on siiski kirjakultuuri mõjuga (Järv 2005: 15). Ülo Valk on aga märkinud, et muistendite puhul võib olla üsna kindel, et käsikirjades olevad pealkirjad on pigem osa koguja tõlgendusest kui jutustaja kõnest (Valk 1998: 23). Viimast toetavad ka mitmed kogujad, kes möönavad, et pealkirjad on nende endi pandud (nt H II 68, $299<$ Koeru khk - Hans Anton Schults), või kurdavad, et ei osanud ühele või teisele loole sobivat pealkirja välja mõelda (E $4266<$ Narva - K. Hanso). Need märkused viitavad sellele, et kogujate jaoks on lugude pealkirjastamine osa kirjapanemise protsessist. Samas ei saa siiski välistada võimalust, et ka suulises kontekstis lugudele mingil moel viidatakse või jutustuse alguses eesootav lühidalt kokku võetakse. Nii on mitmed J. P. Sõggla kirjapandud lood pealkirjastatud vormis „Kuidas...”, näiteks: „Kuida suur raamat ära põletatud”, E 13872/3 (7); „Kuidas sant leiva majasse toonud" (E 13875/6 (9)) - pole võimatu, et see lausekatke kuulus ka jutustaja kõnesse.

Siiski leian, et pealkirju peaks eelkõige käsitlema mitte loo enda juurde kuuluva detailina, vaid konkreetse kommunikatiivse olukorra osana, ning seetõttu on üsnagi loomulik, et viis, kuidas jutustaja oma lugu sisse juhatab, erineb sellest, kuidas kogujad lugusid Eisenile tutvustavad. Eisen omakorda pidi lähtuma sellest, mida ta oma raamatu kui tervikuga lugejatele edastada soovib. Tõsi - seitsme Moosese kogumiku puhul ei paista pealkirjade ühtlustav jõud nii selgelt silma kui näiteks kogumikes „Vanapagana jutud” (Eisen 1893p) ja „Teised Vanapagana jutud” (Eisen 1896b), kus on kasutatud pealkirju ühtlustamaks Vanapagana erinevate nimetuste tekitatud kirjusust: isegi kui konkreetses loos on kasutatud mõnd alternatiivset nimetust, on pealkirjades alati Vanapagan. Seitsme Moosese kogumiku pealkirjad on sellega võrreldes juhuslikumad ja on raske välja tuua mingit selget loogikat, millest lähtuvalt Eisen lugudele pealkirju paneb (või neid muudab). Uus pealkiri võib olla lihtsalt mõnevõrra lühem kui algne (näiteks „Kuidas katk ära kadus”, E 13868/9 (4), asemel „Katku kadumine”, 23. lugu), kuid võib lähtuda ka hoopis teistest märksõnadest (näiteks „Rikas mees ja vaene mees”, E 16294, asemel „Seitse Moosest augus”, 56. lugu). Paaril korral on Eisen siiski kasutanud pealkirju tõstmaks esile mõnd tema arvates tähelepanuväärset detaili. Näiteks on ta kahel juhul viidanud pealkirjas Aadamale ja Eevale („Aadam ja Eeva tööd küsimas”, 15. lugu, käsikirjas pealkirjastamata E 3342/4; „Aadam hauast välja”,14. lugu, käsikirjas „Ahnuse palk”, E 16286).

\subsection{Traditsiooni piiritlemine}

Eisen on teinud lugudes ka mitmeid sisulisi muudatusi. Mõned neist on pigem juhuslikud: näiteks on ta Jakob Ööveli kirjapanekus (E 13517/9 < Tõstamaa khk) asendanud aedniku läbivalt kärneriga (51. lugu). ${ }^{9}$ Teised on suunatud

${ }^{9}$ Sõna kärner esineb Eesti leksikograafias alates S. H. Vestringi käsikirjalisest eesti-saksa sõnaraamatust ( ca 1710-1730), sõna aednik vähemalt alates A. W. Hupeli sõnaraamatu II trükist (1818), XIX sajandi lõpu kirjakeeles olid mõlemad kasutusel, kuid võimalik, et kärner esines mõnevõrra sagedamini. Tänan Udo Uibot, kes seda teemat avada aitas. 
idee selgemale esitusele - ühes J. P. Sõggla kirjapanekus on juttu Eestimaast ja Viljandimaast (E 13868/9 (4) < Halliste khk), Eisen on asendanud Eestimaa Tallinnamaaga (23. lugu), tuues nii selgemalt esile, et mõeldud on kubermangu, mitte eestlaste asuala tervikuna. Eisen on jätnud välja ka kõik viited reaalsetele kirikuõpetajatele ja köstritele (see puudutab lugusid 6, 8, 24, 29 ja 31). Martin Luu kirjapanekust (E 5218b/g (4) < Põltsamaa khk) jättis ta välja lauseosa, kus mainitakse, et enne seitsme Moosese lugemist pani pastor endale kirikukuue selga (22. lugu).

Ent kõige üldisemaks suundumuseks Eiseni versioonides on see, et ta on üritanud vähendada käsikirjade ambivalentsust. Isiklikule suhtumisele viitavate algus- ja lõpuraamide asendamine pealkirjadega oli üheks võimaluseks vähendada üksikisiku kohalolu ja rõhutada anonüümset kollektiivset määramatus ajas elavat rahvast. Lisaks sellele on ta suurendanud (või vähemalt eksplitseerinud) seitsme Moosese osa tekstides endis. Näiteks J. Neublau kirjapandud loos korralikult matmata surnust on mainitud, et kirikuõpetaja r ä äk i s surnuga (E 10612), samas Eiseni versioonis kasutab ta seitset Moosest (24. lugu). J. Ekemanni kirjapandud loos aga pole väidetud, et loo peategelane kasutas seitsme Moosese abi, vaid hoopis viidatud, et tegevuse pealtnägijad a rvas id seda. Eiseni versioonis on kindlalt väidetud, et peategelane kasutas seitset Moosest, ning raamatut on mainitud koguni kahel korral:

Võtnud raamatu, mida lapsed „Seitsmeks Mooseseks" pidanud ja läinud õue. Varsi jäänud torm vaikseks.

J. Ekemann < Tapa, E 6104/7 (19)
Võtnud ise „seitse Moosust” kätte ja läinud sellega õue. Vaevalt läinud õpetaja „seitsme Moosusega” oue, kui torm juba vaikseks jäenud (Eisen 1896a: 166).

Heaks näiteks on ka Jaan Pauski kirjapandud lugu „Jutt Puuslevedamisest ehk nõidumisest" (E 6241/4 < Tarvastu khk). Lugu räägib kahest naabrist, loo alguses kahjustab üks naabritest teist seitsme Moosese abil, järgneb kannatanu (ebaõnnestunud) kättemaksu kirjeldus. J. Pausk mainib seitset Moosest vaid korra loo alguses. Eisen nimetab aga üht naabritest läbivalt „seitsme Moosuse meheks" - tänu sellele on raamatut tema versioonis mainitud seitse korda (35. lugu). Eisen on lisanud loole ka lõpu, mis samuti seitsme Moosese kesksust suurendab: „Sest saadik ei julgenud keegi enam seitsme Moosuse mehele oma nõidumistega kahju teha. Kõik kartsivad teda ja tema raamatut."

Siiski pole Eisen seitsme Moosese alternatiivseid nimetusi oma kogumikust täiesti välja jätnud - kogumiku 60 loo hulgas on 5 teksti, kus seitset Moosest asendab mõni ebamäärasem nimetus: „suur piibel” (12. lugu), „suur raamat” (18. lugu), „vana paks raamat” (23. lugu), „suur must raamat” (46. ja 54. lugu). Viidatud tekstidest kolm esimest on kirja pannud J. P. Sõggel, kaks viimast $\mathrm{O}$. Hintzenberg (nende talletatud tekste ongi raamatus kõige rohkem). Siiski on selline variatiivsus väiksem kui alternatiivsete nimetuste kasutamine käsikirjades. 


\section{Eisen ja seitse Moosest: üldisemaid märkusi}

\subsection{Teadus vs. moraal}

Eiseni raamat jaguneb kaheks osaks: kogujate saadetud lugudele eelneb pikem sissejuhatus „Seitsme Moosese küsimuse arutamine”, kus autor annab ülevaate jututraditsiooni ajaloolis-geograafilisest levikust. Siiski pole sissejuhatuse kõige esileküündivamaks jooneks teaduslikkus - hoopis enam tuleb esile see, mida pidas silmas Ülo Tedre, kirjutades, et Eiseni stiil on „kösterlikkoolmeisterlik või täpsemalt öeldes pastorlik-didaktiline” (Tedre 1996: 172). Ehk siis: kogu teaduslik taust on esitatud selleks, et veenda lugejat seitsme Moosese ebareaalsuses ning tema olemasolusse uskumise ebamoraalsuses.

Eiseni selgelt moraliseeriv lähtepunkt oli ühelt poolt kindlasti seotud tema ametiga - kuulus ju ebausu väljajuurimine pastori ametiülesannete hulka. ${ }^{10}$ Teisalt võis sellist rõhuasetust mõjutada ka asjaolu, et 1893. aastal, kui Eisen asus seitsme Moosesega seotud materjale koguma, toimus ajakirjanduses debatt selle üle, kas Hurda ja Eiseni paralleelsest kogumistööst sünnib eesti rahvale pigem kasu või kahju. Vaidluse üheks tulipunktiks oli Eiseni komme kogutu kohe trükki anda - kommenteerijad, kes olid sellise teguviisi vastu, tundsid muret, et sellise kiirustamise juures võib sisse jääda palju ebamoraalset, viimane omakorda võib aga rahvaluulekogumist üldsuse silmis diskrediteerida (vt nt Eesti vanavara 1893; Kikas 2013: 344). ${ }^{11}$ On üsnagi kõnekas, et pikema sissejuhatusega raamatud ilmuvad Eiseni repertuaari just tülijärgsel ajal - seitsme Moosese raamatuga paralleelselt koostas ta seda laadi väljaanded ka kratist (Eisen 1895e), luupainajast (Eisen 1896c) ja näkist (Eisen 1897). Seega võib eeldada, et üheks põhjuseks, miks ta seesuguseid sissejuhatusi lisama hakkas, oli soov luua väljaandeid, millele ei oleks saanud ette heita moraalseid küsitavusi. ${ }^{12}$

Üsnagi kõnekas on järgnev lõik sissejuhatusest, kus ta oma (teadusest ja kristlikust moraalist lähtuva) seisukoha ja rahva seisukoha selgelt lahku lööb:

Ennemalt tähendasin juba, et seitset Moosest selgeks luulevalla sünnituseks ilma mingisuguseta tõe põhjata tuleb pidada. Edespidi astuvad meile mõnedki tükid seitsme Moosese kohta seda viisi silma ette, nagu seisaksivad nad kindlal alusel. See kindlal alusel seismine jäeb ainult silmakirjaks. Rahva arvamist seitsme Moosese kohta katsusin tihti otse rahva sõnadega üles panna. Et nüüd rahvas kindlasti seitsme Moosese sisse usub, näitab lugu edespidi mõnegi korra, nagu usuks raamatu kirjutaja sedasama. Kes neid ridasid ja eelpool olevaid raamatu kirjutaja oma kirjutatud seletusi

${ }^{10}$ Eisen on seitsme Moosese teemat sarnasest vaatepunktist käsitlenud ka 1887. aastal ilmunud näidendis „Kuidas nõiaks saab?”. Selles näidendis satub tallu võõras, kel kaasas suur raamat. Kohalikud peavad raamatut seitsmeks Mooseseks ning nõuavad, et ta selle abil ühe hiljutise varguse lahendaks. Mees ise väidab, et tegu on tavalise raamatuga, kuid paljast hirmust raamatu võlujõu ees tunnistavad vargad ise oma teo üles. Võõras aga rõhutab, et tegu ei paljastanud mitte tema raamat, vaid inimeste endi ebausk (vt Eisen 1887).

${ }^{11}$ Samasugust seost loetavuse ja moraalinormide vahel on esile toonud ka Richard Bauman, analüüsides Henry Rowe Schoolcrafti tekstuaalseid praktikaid (Bauman 2001: 59, 62).

${ }^{12}$ Võimalik, et ka otsus lugudest reaalsete kirikuõpetajate nimed välja lõigata lähtus samast impulsist - viitasid ju rahvaluulekogumise vastased sageli sellele, et tegu on pastorile sobimatu tegevusega. 
läbi lueb, piab aru saama, et rahva arvamised Seitsme Moosese kohta ja seitse Moosest ise nagu õhu loss põrmuks kokku langevad, jah, selle lossi põrmgi kaob käest! (Eisen 1896a: 10).

Samas on oluline, et selline moraliseeriv raam ei ümbritse selles väljaandes mitte üksnes seitsme Moosese raamatut, vaid kohati folkloori kui tervikut. Paistab, et Eiseni eelistatud üldmõiste rahvaluule ${ }^{13}$ annab vägagi häid võimalusi keelemängudeks, mis lubavad rõhutada nähtuse fiktsionaalsust:

Kuid rahvas ei märganud seda sõlme seitsme Moosese imelikka lugusid luuletades. Me võiksime veel mõnda sarnast küsimist tõsta, aga mis tarvis? Rahva luuletus ei jaksa iialgi teaduse ees seista ega uurijale kõigi küsimiste peale vastust anda (Eisen 1896a: 56).

Võru poolt rahvas ei arva seda kohaseks, et sarnane raamat raudahelates seisab; Võrulaste luulevaim ja Tagapeipsi rahva arvamine on ahelad hõbedaseks muutnud (Eisen 1896a: 67-68).

Küll luuletab rahvas ka „seitsmele Moosesele” ettekuulutused tuleviku kohta suhu, aga need ettekuulutused on ainult osa ta sisust (Eisen 1896a: 102).

Siin oli Pegasusele maad sõitmiseks küllalt. Luulejõud lõi ära võetud piiblid seitsmeks Mooseseks (Eisen 1896a: 117).

Võimalik, et Eisen pidas luuletamist leebemaks väljendiks kui valetamine, ent avaramal taustal tekitab see sõnakasutus küsimuse, kuidas ta terminit rahvaluule mõtestas ning kuivõrd teadlikult paigutas ta oma termini keskmesse verbi, mis justkui soodustas nähtuse alavääristamist.

\subsection{Nimetamise küsimus}

Traditsiooni piiritlemise seisukohast on aga oluline ka üks üldisem küsimus, mille käsitlemist ma siiani olen vältinud: mil moel mõjutas kogumise tulemusi see, kuidas Eisen materjale nõutas. Ehk siis: kas seitse Moosest oli tõepoolest kõige levinum nimetus või tundub meile nii sellepärast, et Eisen oma üleskutsetes keskendus sellele nimetusele (alternatiivne „must raamat” esines vaid kõige esimeses ajalehetekstis, vt Eisen 1893a)? Millised oleksid tulemused olnud siis, kui Eisen oleks küsinud hoopis üldisemalt nõidumiseks kasutatavate raamatute järgi? Ning kas tema valik just „seitsme Moosese” kasuks oli kuidagi seotud raamatu tarvis kavandatud raamistusega?

Toetudes materjalidele, mis on koondatud seda üht märksõna silmas pidades, pole kahele esimesele neist küsimustest ilmselt võimalik vastata. Laekunud materjalides esineb ka muid sünonüümseid nimetusi, kuid seitse Moosest on vaieldamatult kõige valdavam. Samas tuleneb see osaliselt sellest, et kogujad kasutavad „seitset Moosest” pealkirjades jm raamides isegi siis, kui narratiivides on esil sünonüümid.

${ }^{13}$ Rahvaluule mõiste võttis Eisen kasutusele 1893. aastal vastukaaluna Hurda eelistatud vanavarale. Eisen rõhutas, et tema arvates kirjeldab rahvaluule paremini nähtuste vaimset, mittemateriaalset olemust (Eisen $1893 \mathrm{~m}$, eesti folkloristika terminoloogia arengu kohta vt Jaago 1999). 
Küsimustest kolmas on aga põnevam. Põnevam juba seetõttu, et Eisenit võib ju pidada eesti folkloristika ristiisaks ja süstematiseerijaks (Tedre 1995: 169, 1996: 175). On mitmeid rahvaluulevaldkondi, mille üldnimetusena kasutatakse seda, mille Eisen välja on valinud. Näiteks on Eisen kindlasti üks neist, tänu kellele me eelistame kõikidest sünonüümidest vanapaganat - just see nimetus on kasutusel nii tema jutukogumike kui ka neis leiduvate narratiivide pealkirjades (Viires 2001). Eiseni valikut just selle nimetuse kasuks mõjutas võimalus etümoloogia 'vana pagan' abil rõhutada tegelase positiivsust ning tema vastase Kaval-Antsu ebamoraalsust (Eisen 1903, 1905); just see nimetus võimaldas tal esitada Vanapagana ja Kaval-Antsu lugusid kui olulist osa eestlaste pärimusest, ülistamata samas Kaval-Antsu kavalust, vaid rõhutades tema tegude ebamoraalsust. Viimast näidet analoogiana kasutades võib oletada, et Eiseni otsus seada keskmesse just nimetus „seitse Moosest” lähtus soovist rõhutada jututraditsiooni seost piibliga, s.o seda, et tegu on millegagi, mis on selgelt vastuolus ametliku kristlusega. Selline nime kaudu kontekstualiseerimine muutis ka nähtuse kummutamise kergemaks: väga kerge oli tõestada, et piiblis pole kunagi niisuguseid osiseid olnud.

\section{Kokkuvõtteks}

Siinses artiklis esitasin ühe jututraditsiooni teekonna suulisest kultuurist käsikirjalisse arhiivi ning sealt edasi raamatusse. Protsessis osales suur hulk inimesi, kes osaliselt üheskoos, osaliselt teineteisele vastanduvalt jutustasid, meenutasid, kirjutasid ja tõlgendasid seitsme Moosesega seotud lugusid. Eiseni lähtepunkt lugusid küsides ning raamatut kokku pannes oli üsnagi selge - soov näidata pärimuse paikapidamatust - ning hoolimata käsikirjades ilmnevatest erimeelsustest, jõudis avalikku ruumi just tema nägemus. Mitmehäälsuse vähendamine anonüümse rahva esiletõstmise arvelt võimaldas paigutada teema määramatusse minevikku, millel kaasaegsete inimestega justkui pistmist polegi. Seitsme Moosese kohalolu eksplitseerimine lugudes ning lugude vormistamine võimalikult ühetaoliselt võimaldas anda muidu amorfsele ja ambivalentsele traditsioonile selgemalt piiritletud keskme. Viimane oli oluline nii traditsiooni eripärade esiletoomiseks kui ka selle ümberlükkamiseks - vastustada saab ju ikkagi vaid seda, mille olemust on võimalik määratleda.

Samas võime siiski tõdeda, et raamat ei täitnud Eiseni seatud moraalset eesmärki, s.o see ei toonud kaasa seitsme Moosese pärimuse hääbumist. Lugusid selle nähtuse kohta, nagu ka kuulujutte ravitsejatest, kellel on see raamat kindlasti olemas, on kirja pandud ka aastakümneid hiljem. Ka võib raamatu ilmumise järgsest ajast leida arhiivitekste, milles kohalikud kogujad vaidlustavad Eiseni tõlgenduse ning toovad tõendeid nähtuse reaalsuse kohta. Seega võib öelda, et tänapäeva vaatevinklist osutus Eiseni raamat ühes lüliks selle nähtuse arengus - lüliks nii teaduslikus mõttes (kui katse selle tagamaid seletada ning levikut eestlaste seas kaardistada) kui ka jututraditsiooni elavdamise mõttes.

Artikkel on seotud institutsionaalse uurimistoetusega IUT22-5 ja riikliku programmiga „Eesti keel ja kultuurimälu” (EKKM14-389). 


\section{Kirjandus}

AaS = Antti Aarne 1918. Estnische Märchen- und Sagenvarianten. Verzeichnis der zu den Hurt's Handschriftsammlungen gehörenden Aufzeichnungen. (FF Communications 25.) Hamina: Suomalaisen Tiedeakatemian Kustantama.

A n d e r s o n, Walter 1929a. Die Universität Dorpat in der estnischen Volksüberlieferung: Festvortrag, gehalten am 90. Jahrestage der Gesellschaft den 18. Januar 1928 (mit späteren Ergänzungen). - Sitzungsberichte der Gelehrten Estnischen Gesellschaft. Dorpat: C. Matthiesen, lk 9-44.

A n d e r s o n, Walter 1929b. Das sechste und siebente Buch Mosis in Norwegen. Sitzungsberichte der Gelehrten Estnischen Gesellschaft. Dorpat: C. Matthiesen, lk 203-204.

A n d e r s o n, Walter 1938. Eisen ja Hurt rahvaluulekogujaina. - M. J. Eiseni elu ja töö. Tartu: Noor-Eesti, lk 130-132.

ATU = Hans-Jörg Uther 2004. The Types of International Folktales. A Classification and Bibliography. Based on the System of Antti Aarne and Stith Thompson. I-III. (FF Communications 284-286.) Helsinki: Suomalainen tiedeakatemia.

$\mathrm{B}$ a u m a n, Richard 2001. Representing native American oral narrative. The textual practices of Henry Rowe Schoolcraft. - Languages and Publics. The Making of Authority, lk 46-65.

Briggs, L. Charles 1993. Metadiscursive practices and scholarly authority in folkloristics. - The Journal of American Folklore, kd 106, nr 422, lk 387-434.

Eesti vanavara 1893 = Eesti vanavara korjamisest ja keelemurrete uurimisest. Postimees 17. VIII.

E i s e n, M. J. 1887. Kudas nõiaks saab. Nali ühes näituses. Tartu: Schnakenburg.

E i s e n, Matthias Johann 1893a. Rahvaluule korjamine. - Sakala 17. III; Eesti Postimees 18. III; Virmaline 24. III.

E i s e n, Matthias Johann 1893b. Rahvaluule korjamine. - Sakala 12. V; Postimees 5. V; Virmaline 5. V; Eesti Postimees 15. V.

E i s e n, Matthias Johann 1893c. Rahvaluule korjamine. - Postimees 28. V; Virmaline 2. VI; Eesti Postimees 5. VI; Sakala 5. VI.

E is e n, Matthias Johann 1893d. Rahvaluule korjamine. - Virmaline 14. VII; Sakala 14. VII; Eesti Postimees 10. VII; Postimees 5. VII.

E i s e n, Matthias Johann 1893e. Rahvaluule korjamine. - Sakala 18. VIII; Virmaline 18. VII; Eesti Postimees 2. IX; Postimees 21. IX.

E i s en, Matthias Johann 1893f. Rahvaluule korjamine. - Sakala 15. IX; Eesti Postimees 18. IX; Virmaline 9. X; Postimees 27. IX.

E i s e n, Matthias Johann 1893g. Rahvaluule korjamine. - Sakala 22. IX; Virmaline 17. IX; Postimees 28. IX; Eesti Postimees 25. IX.

E i s e n, Matthias Johann 1893h. Rahvaluule korjamine. - Virmaline 29. IX; Sakala 6. X; Postimees 11. X.

E i s e n, Matthias Johann 1893i. Rahvaluule korjamine. - Eesti Postimees 20. X; Sakala 14. X; Postimees 15. X.

E i s e n, Matthias Johann 1893j. Rahvaluule korjamine. - Postimees 20. X; Sakala 27. X.

E i s e n, Matthias Johann 1893k. Rahvaluule korjamine. - Postimees 26. X.

E i s e n, Matthias Johann 1893l. Rahvaluule korjamine. - Postimees 8. XI; Sakala 10. XI.

E i s e n, Matthias Johann 1893m. Rahvaluule ja selle avaldamine. - Eesti Postimees 15. XI. 
E i s e n, Matthias Johann 1893n. Rahvaluule korjamine. - Postimees 13. XII; Eesti Postimees 13. XII.

E i s e n, Matthias Johann 1893o. Rahvaluule korjamine - Eesti Postimees 13. XII; Postimees 15. XII; Sakala 5. I 1894.

E i s e n, Matthias Johann 1893p.Vanapagana jutud. Rahva suust kokku korjatud. Esimene raamat. Tallinn: K. Busch.

E i s e n, Matthias Johann 1894a. 7. Moosese raamatu kohta. - Postimees 8. XI; Eesti Postimees 26. XI; Sakala 9. XI; Linda 11. XI.

E i s e n, Matthias Johann 1894b. Veel 7 Moosesest. - Eesti Postimees 24. XII; Postimees 7. XII; Linda 16. XII.

E i s e n, Matthias Johann 1895a. Koerakoonlased ja peninukid. - Postimees 4. VII. E i s e n, Matthias Johann 1895b. Seitsmest Moosesest. - Eesti Postimees 21. VII. E i s e n, Matthias Johann 1895c. Rahvaluule korjamine. - Postimees 21. VII; Eesti Postimees 4. VIII; Linda 28. VII.

E i s e n, Matthias Johann 1895d. Rahvaluule korjamine. - Eesti Postimees 22. IX; Linda 22. IX.

E i s e n, Matthias Johann 1895e. Krati-raamat. Katse Tulihänna ja ta suguseltsi seletuseks ja 40 juttu tulihännast, puugist ja wedajast. Narva: R. Põder.

E is e n, Matthias Johann 1896a. Seitse Moosese raamatut. Katse kuuenda ja seitsmenda Moosese raamatu seletuseks. Tallinn: K. Busch.

E i s e n, Matthias Johann 1896b. Teised Vanapagana jutud. Rahva suust kokku korjatud. Tallinn: G. Pihlakas.

E i s e n, Matthias Johann 1896c. Luupainaja. Seletused luupainaja kohta ja 25 juttu luupainajast. Narva: R. Põder.

E i s e n, Matthias Johann 1897. Näki raamat. 65 juttu näkist ja Lisa. Tallinn: T. Turgan.

E i s e n, Matthias Johann 1903. Ametist lahti lastud vanapagan. - M. J. Eisen, Vahepalukesed. Tallinn: J. Ploompuu, lk 61-72.

E is en, Matthias Johann 1905. Kavala Hansu ja vanapagana lugu. Tallinn: G. Pihlakas.

J a a g o, Tiiu 1999. Rahvaluule mõiste kujunemine Eestis. - Mäetagused, nr 9, lk 70-91.

J ärv, Risto 2005. Eesti imemuinasjuttude tekstid ja tekstuur. Arhiivikeskne vaatlus. Tartu: Tartu Ülikooli Kirjastus.

K i k a s, Katre 2013. Ajakirjandus Jakob Hurda ja Matthias Johann Eiseni rahvaluulekogumise mõtestajana. - Keel ja Kirjandus, nr 5, lk 333-350.

Kirjandusest 1895. - Postimees 16. IX; Eesti Postimees 22. IX.

Kues ja seitsmes Mosese Raamat. 1. jagu. Rakvere: L. Oppermann, 1872.

K u rki, Tuulikki 2002. Heikki Meriläinen ja keskusteluja kansanperinteestä. Helsinki: Suomalaisen Kirjallisuuden Seura.

K u u t m a, Kristin 2005. Matthias Johann Eisen: A collector and publisher of narratives. - Studies in Estonian Folkloristics and Ethnology. A Reader and Reflexive History. Tartu: Tartu University Press, lk 79-99.

Kõ i va, Mare 2014. Palindromes and letter formulae: Some reconsiderations. Trough the Ages I. Folklore as a Common Expression of Lingual, Figurative, Emotional and Mental Memory. (Sator 5.) Tartu: ELM Scholarly Press.

P a a t si, Vello, P a a ts i, Kristi 2008. Raamat eestlaste eluringis. - Kes kõlbab, seda kõneldakse. Pühendusteos Mall Hiiemäele. (Eesti Rahvaluule Arhiivi toimetused 25.) Tartu: Eesti Kirjandusmuuseumi Teaduskirjastus, lk 57-73. 
Põld mä e, Rudolf 2011. Vennastekoguduse säilinud käsikirjad. - R. Põldmäe, Vennastekoguduse kirjandus. (Eesti mõttelugu 101.) Tartu: Ilmamaa, lk 398-424.

P ä s s, Elmar 1938. Eiseni rahvaluulekogudest. - M. J. Eiseni elu ja töö. Tartu: Noor-Eesti, lk 133-139.

$\mathrm{S}$ a u k a s, Rein 2003. Matthias Johann Eisen mõistatuste kogumise organiseerija ja publitseerijana aastatel 1869-1890. - Mäetagused, nr 21, lk 85-140.

T e d r e, Ülo 1994. M. J. Eiseni tee folkloristikasse (II). Eisen Hurda võistlejana. Keel ja Kirjandus, nr 8, lk 487-497.

T e d r e, Ülo 1995. Järelsõna. - M. J. Eisen, Eesti mütoloogia. Tallinn: Mats, lk 163-172.

T e d r e, Ülo 1996. Matthias J. Eisen rahvausundi uurijana. - M. J. Eisen, Esivanemate ohverdamised. Tallinn: Mats, lk 170-177.

V a 1 k, Ülo 1998. Allilma isand. Tartu: Eesti Rahva Muuseum.

V a lk, Ülo 2008. Saksad ja varavedajad: eesti muistendite sotsiaalsest orientatsioonist. - Kes kõlbab, seda kõneldakse. Pühendusteos Mall Hiiemäele. (Eesti Rahvaluule Arhiivi toimetused 25.) Tartu: Eesti Kirjandusmuuseumi Teaduskirjastus, lk 57-73.

V i i r e s, Ants 2001. Kui vana on vanapagan? - A. Viires, Kultuur ja traditsioon. Tartu: Ilmamaa, lk 69-84.

\section{Matthias Johann Eisen and his coworkers defining the folklore on Seven Moseses}

Keywords: folklore collection, M. J. Eisen, the Sixth and Seventh Books of Moses, publication of folklore

The article is focused on the folktale publication „Seven Moseses. An Attempt to Explain the Sixth and Seventh Books of Moses" (1896) compiled by Matthias Johann Eisen. According to Estonian folklore, the original Bible contained seven books of Moses, and although the $6^{\text {th }}$ and $7^{\text {th }}$ were removed from the official version long ago, some of the copies are still in use - and there are a lot of folktales telling about people who own the book and the deeds they do with the help of it.

Eisen started to amass materials for his publication in 1893 - as usual at the time, he collected only some of the tales himself, while the rest were sent to him by local collectors who learned about his wishes from the texts he published in several newspapers. As the relevant texts recorded before Eisen's project were really few, we can say that his project was not only about the book but also about defining a specific folktale topic as part of Estonian folklore.

Looking from this angle we can see that the vantage points of Eisen and the local collectors must have differed quite distinctly. In the writings of the collectors, the identity of the Seven Moseses is quite ambivalent and the topic has remarkably close links to other fields of folklore. Eisen on his part has tried to minimize those ambivalences and present the theme as something self-contained and independent - in his publication the tales are not embedded in the wider context of folklore anymore but are given an evaluative interpretation from the viewpoint of Christian morality.

Katre Kikas (b. 1981), MA, Estonian Literary Museum, Department of Folklore, researcher; University of Tartu, Doctoral Student, katreki@folklore.ee 